Volume 6

Number 3 Survey on Oil \& Gas

Article 21

2020

\title{
A Comparative Analysis of Texas and New Mexico Oil and Gas Laws from a Title Examiner's Perspective
}

Carly Hewett

chewett@chmslaw.com

Follow this and additional works at: https://scholarship.law.tamu.edu/journal-of-property-law

Part of the Oil, Gas, and Mineral Law Commons, and the Property Law and Real Estate Commons

\section{Recommended Citation}

Carly Hewett, A Comparative Analysis of Texas and New Mexico Oil and Gas Laws from a Title Examiner's Perspective, 6 Tex. A\&M J. Prop. L. 225 (2020).

This Student Article is brought to you for free and open access by Texas A\&M Law Scholarship. It has been accepted for inclusion in Texas A\&M Journal of Property Law by an authorized editor of Texas A\&M Law Scholarship. For more information, please contact aretteen@law.tamu.edu. 


\section{A Comparative Analysis of TeXas And New MeXico Oil And Gas LAWS FROM A TITLE EXAMINER's PERSPECTIVE}

\section{Carly Hewett ${ }^{\dagger}$}

\section{INTRODUCTION}

The statutory framework surrounding oil and gas law and the related title issues in Texas and New Mexico, while similar in many instances, do have some notable differences. New Mexico case law is very limited, which could be due to a variety of reasons, including a smaller state population and the fact that New Mexico and the United States own much of New Mexico's oil and gas productive acreage. Therefore, practitioners often look to other jurisdictions, including Texas, for guidance. Texas's secondary authority is also better developed with its own adopted title standards. ${ }^{1}$ New Mexico does not have such guidance. This Article will focus on the distinctions between the oil and gas laws and the passage of title in Texas and New Mexico from a title examiner's perspective. Both states do have a regulatory body - the Texas the Railroad Commission ("TXRRC") and the New Mexico Oil Conservation Division ("NMOCD") ${ }^{2}$ - that oversees oil, gas, and other mineral activities by regulating activities such as well spacing, allowables, and pooling.

\section{HISTORY}

One of the significant differences in examining title in New Mexico is that millions of mineral acres are held by the state and managed by the State Land Commissioner or by the United States and managed by the Bureau of Land Management. The history and the differences in the way Texas and New Mexico became states explains the reason for this discrepancy in mineral ownership.

In 1846, the New Mexico territory was surrendered to the United States, at which time the land not previously granted by Spain

DOI: https://doi.org/10.37419/JPL.V6.I3.21

${ }^{\dagger}$ Carly Hewett is a founding partner of Childers, Hewett, Myers \& Slagle, PLLC, and primarily represents oil and gas companies in their exploration and production operations, including title, transactional, and regulatory matters. Carly is licensed to practice law in both Texas and New Mexico.

1. See Tex. Prop. Code AnN. Tit. 2 App. (West 2018).

2. See TeX. NAT. Res. CodE $\S 81.052$ (West 2018); N.M. StAT. AnN. $§ 19-1-1$ (1978). 
or Mexico and approved by the United States' regulatory framework was transferred to the United States. Subsequently, a variety of land acts, including the Organic Act of 1850, the Ferguson Act of 1898, and the Enabling Act of 1910, allotted sections of land for the public benefit, which land is now held by the State of New Mexico. ${ }^{3}$ The result of this is that approximately nine million surface acres and thirteen million subsurface acres of land in thirty-two of New Mexico's thirty-three counties are owned by the State. New Mexico's Commissioner of Public Lands manages all such state trust lands for the benefit of public schools, universities, hospitals, and other public institutions. The United States has retained over four million mineral acres of land in New Mexico, and there are almost 8,000 federal oil and gas leases covering land in the state. ${ }^{4}$

Unlike New Mexico, when Texas was annexed into the United States in 1845, the state maintained all its land. Therefore, Texas does not include any federal lands managed by the Bureau of Land Management. Prior to statehood, the Republic of Texas dedicated fifty-two million acres of land to finance public education, and the Texas State Constitution of 1854 dedicated one-tenth of the public revenue to a perpetual fund for public schools. ${ }^{5}$ The intent was that the land be sold with the revenue deposited to the Public School Fund. Presently, the General Land Office is responsible for the management of more than twelve million acres of land dedicated to the Public School Fund, and the land is rarely sold. ${ }^{6}$ For the land that was sold, the state did not maintain any mineral interest if sold prior to September 1, 1895. Land sold between 1895 and 1931 was sold subject to the Relinquishment Act, and the state maintained mineral ownership with the landowner holding leasing rights, subject to approval from the General Land Office. Lease benefits are shared

3. The Organic Act, 9 Stat. 446 (1850); Ferguson Act, 30 Stat. 484 (1898); New Mexico-Arizona Enabling Act of 1910, 36 Stat. 557 (1910).

4. Oil and Gas Statistics, U.S. DePt. InTERIOR Bureau LAND MGMT. https:/www.blm.gov/programs/energy-and-minerals/oil-and-gas/oil-and-gasstatistics [https://perma.cc/82FQ-HSKA] (Last visited Nov. 3, 2019).

5. An Overview of the History of Public Education in Texas, TEX. EduC. AGENCY

https://tea.texas.gov/About_TEA/Welcome_and_Overview/An_Overview_of the History_of Public_Education_in_Texas [https://perma.cc/65A $\overline{3}-Z R 35]$ (last visited Nov. 3, $20 \overline{19})$.

6. The Texas Constitution Of 1876 Set Aside Half of Texas' Remaining Public Lands to Establish a Permanent School Fund (PSF), To Help Finance Public Schools, TEX. GEN. LAND OFF., http://www.glo.texas.gov/land/landmanagement/overview/index.html [https://perma.cc/DG2X-3MWB] (last visited Oct. 30, 2019). 
between the landowner and the state. ${ }^{7}$ The Sales Act of 1931 superseded the Relinquishment Act, under which certain land was designated as mineral land. The state retained a non-participating royalty interest in said mineral land. For land sold after June 19, 1983, there is no longer a mineral land classification.

An 1883 Texas law provided for dedicated University Lands, and today approximately two million acres of lands in Texas are leased by the Board for the Lease of University Lands. The state manages these lands for the benefit of the Permanent University Fund, which benefits institutions across the University of Texas and Texas A\&M University systems. ${ }^{8}$

\section{OWNERSHIP}

Ownership of fee interests in both states is similar in that the mineral estate is severable from the surface estate and the mineral estate is dominant. However, New Mexico has enacted a Surface Owners Protection Act that grants rights to private fee landowners and surface tenants. Additionally, the Act outlines procedures that must be followed before an oil and gas lessee can enter the surface of the land for purposes of exploration, drilling, and production. ${ }^{9}$ Under the Act, five days' notice must be given for non-surface disturbing activities and thirty days' notice for surface disturbing activities. ${ }^{10}$ If the surface owners refuse to enter into an agreement with the lessee, the lessee may still enter the land but must post a bond prior to doing so and beginning operations. ${ }^{11}$ Under Texas case law, absent a contractual obligation provided for within the lease, a landowner seeking to recover from the lessee for damages to the surface must prove either specific acts of negligence or that the lessee used more of the land for oil and gas production than was reasonably necessary. ${ }^{12}$ Protection for surface owners has not been codified.

7. Originally codified as TEX. REV. CIV. StAT. AnN. art. 5368, the Relinquishment Act is now codified as TEX. NAT. RES. CODE ANN. ch. 52, subch. F (§§ 52.171-.186) (Vernon 1978 and Supp. 1985).

8. History of Texas Public Lands, TEX. GEN. LAND OfF. 17 (Mar. 2018), http://www.glo.texas.gov/history/archives/forms/files/history-of-texas-publiclands.pdf [https://perma.cc/CTN9-J48T].

9. N.M. STAT. AnN. $\S \S 70-12-1$ to -10 (West 1978).

10. $\$ 70-12-5(\mathrm{~A})-(\mathrm{B})$.

11. $\$ 70-12-6$.

12. Humble Oil \& Ref. Co. v. Williams, 420 S.W.2d 133, 134 (Tex. 1967). 
Adverse possession is another issue related to real property ownership that is similar in both states but does have some notable distinctions. Namely, Texas statutes provide for four different periods of continuous possession - being three, five, ten, and twenty-five years - for which different requirements exist to acquire land through adverse possession. ${ }^{13}$ New Mexico statutes provide for one ten-year statutory period for adverse possession, but color of title is always a requirement. ${ }^{14}$ In both states, government owned land is generally immune from adverse possession actions, and when the surface and minerals have been severed, adverse possession of the surface does not mean adverse possession of the minerals.

\section{OIL AND GAS LEASE}

The courts in Texas have adopted the four corners approach when interpreting contracts, including oil and gas leases. Alternatively, New Mexico courts use a contextual approach. For practical purposes, this can be a challenge for practitioners in New Mexico because even if the terms of the document are not ambiguous, the court can still consider circumstantial evidence to determine the intent of the parties. ${ }^{15}$ While standard forms are used to lease New Mexico state and federal land and land controlled by the General Land Office in Texas, there is no statutorily required form for fee oil and gas leases in either state.

All oil and gas leases provide for royalties payable on production from the land covered thereby. Both Texas and New Mexico have statutory time periods for the payments of royalties, but they are slightly different. Under the New Mexico Proceeds Payment Act, royalty payments must be made no later than six months after the first day of the month following the date of first sale, and after that, no later than forty-five days after the end of the calendar month in which payment is received by the payor. ${ }^{16}$ Late payments will accrue interest, and a Lessor cannot contract this requirement away. ${ }^{17}$ Similarly, under the Texas Time for Payment of Proceeds Act, royalty payments must be made no later than 120 days after the first date of

13. TeX. Civ. Prac. \& ReM. Code ANN. §§ 16.024-16.026, 16.028 (2018).

14. N.M. STAT. ANN. § 37-1-22 (2019).

15. C.R. Anthony Co. v. Loretto Mall Partners, 817 P.2d 238, 242-43 (N.M. 1991).

16. N.M. STAT. ANN. § 70-10-3 (2019).

17. First Baptist Church of Roswell v. Yates Petroleum Corp., 345 P.3d 310 (N.M. 2015). 
sale. ${ }^{18}$ If a time for payment is not specified in the lease or other written agreement, subsequent proceeds must be paid sixty days after the end of the calendar month in which oil production is sold. The payment time period is ninety days for gas production. ${ }^{19}$ Of course, if there is a reasonable title dispute, royalties can be withheld without interest in both states.

\section{RECORDING AND CONSTRUCTIVE NOTICE}

To provide notice of a conveyance of an interest in real property, it is necessary in both states to record the conveyancing instrument with the county clerk where the property is located. ${ }^{20}$ The notable difference in recording requirements between Texas and New Mexico is due to the existence of New Mexico state and federal lands. Instruments affecting title to federal oil and gas leases must be recorded in the county records where the property is located, as well as with the Bureau of Land Management. ${ }^{21}$ The federal records do not impart constructive notice as they are used only for administrative purposes. However, all instruments must be double filed. Instruments affecting title to state of New Mexico oil and gas leases need only be filed with the Commissioner of Public Lands and do not need to be filed twice because the state records do impart constructive notice. ${ }^{22}$

\section{POOLING}

Pooling is the consolidation of two or more leases to form a spacing or proration unit and is utilized by operators and allowed by mineral owners to promote geologic, business, and administrative efficiency. Communitization is the same concept but used when state and federal lands are included. Often a tract of land is too small to obtain a well permit, and thus multiple tracts are pooled together to form sufficient acreage to comply with spacing rules. ${ }^{23}$ Pooling can be voluntary — where all interest owners agree to pool their interests

18. TeX. NAT. RES. CODE ANN. § 91-402 (West 2011).

19. Id.

20. N.M. Stat. AnN. $\S 14-9-1$ to -3 (2019); Tex. Prop. Code AnN. $§ 13.001$ (2014).

21. N.M. STAT. AnN. § 70-1-1 (2019).

22. N.M. STAT. AnN. § 19-10-31 (2019).

23. N.M. Stat. AnN. § 70-2-17 (2019); TeX. NAT. Res. Code AnN. § 102.011 (West 2019). 
together by delegation, as conveyed in an oil and gas lease-or through a statutorily forced pool.

Both Texas and New Mexico have mechanisms for an oil and gas operator to forcibly pool interests together through their respective state regulatory agencies. The NMOCD can compulsorily pool lands and interests together to form a spacing unit, despite the owner's nonjoinder, to avoid the drilling of unnecessary wells and to prevent waste. ${ }^{24}$ An operator proposing a well must apply to the NMOCD and have a compulsory pooling hearing. A compulsory pooling order is then issued, which requires drilling within a certain time period. The order also sets out a one-eighth royalty interest to be paid to the compulsory pooled interest owner if the owner does not elect to participate in its share of the costs of drilling the well. In that case, the pooled owner will be carried to payout and not charged drilling costs. The compulsory pooled owner, however, will have to pay a penalty to compensate for the risk of drilling and the lack of paying upfront costs. If the parties are able to come to a voluntary agreement, the one-eighth royalty interest will fall out of the order and the terms of the voluntary agreement will prevail. If an operator fails to obtain a voluntary pooling agreement or a pooling order from the NMOCD, the unpooled interest owner will be entitled to either the interest it would be entitled to if pooling had occurred or the amount it would be entitled to in the absence of pooling, whichever is greater. ${ }^{25}$

The TXRRC, through the authority granted in the Mineral Interest Pooling Act, will pool lands and interests together as a last resort only if fair and reasonable negotiations failed to result in an agreement. $^{26}$ The purpose of the Act is to encourage voluntary pooling, to protect correlative rights, and to prevent waste. The Mineral Interest Pooling Act does not cover lands owned by the state or lands that the state has a direct or indirect interest in. Operators have been allowed to use the Mineral Interest Pooling Act to pool small tracts despite opposition, and the mineral owner is granted a onefifth royalty interest and no risk penalty. ${ }^{27}$ Unlike New Mexico, in Texas, an owner of an unleased tract of land can use the Mineral Interest Pooling Act to force its way into a pooled unit if they do not receive a fair voluntary pooling offer. This is because in Texas, an unleased owner of a non-drill site tract will not receive a share of

24. N.M. Stat. AnN. § 70-2-17 (2019).

25. N.M. STAT. AnN. §70-2-18(B) (2019).

26. TEX. NAT. RES. $\S \S 102.011,102.013$ (West 2019).

27. TEX. NAT. RES. $\S \S 102.001-.018$ (West 2019). 
production, and the Lessee has no duty to offer them a right to participate in the pooling.

New Mexico has yet to rule on issues related to pooling of overriding royalty and non-participating royalty interests. An overriding royalty interest is carved out of an existing leasehold interest and reduces the working interest owner's net revenue interest. Current Texas case law supports the statement that an overriding royalty owner does not need consent to pool its interest if the underlying lease contains a pooling clause. ${ }^{28}$ While New Mexico has not specifically ruled on this topic related to leases of fee mineral interests, we note that New Mexico oil and gas leases and United States oil and gas leases do not include pooling provisions. Interests in state and federal leases must be communitized and approved by the Commissioner of Public Lands or the Bureau of Land Management, respectively. Overriding royalty owners in state and federal leases must first be invited to join the communitized unit. If the owner does not consent, a compulsory pooling application must evidence the "reasonable effort" made to obtain consent. ${ }^{29}$

A non-participating royalty interest is carved out of the mineral interest and reduces the mineral interest owner's royalty interest. Under Texas case law, a ratification of the pooling provision of an oil and gas lease is required to pool an owner of a non-participating royalty interest. ${ }^{30}$ New Mexico has not ruled on this issue, but practitioners often assume Texas law would be followed. It is important to note that conveyances of overriding royalty interests or non-participating royalty interests can include provisions specifically stating that consent is not required to pool the interest being conveyed, in which case the language in the document creating the interest would rule.

\section{MARITAL PROPERTY}

Both Texas and New Mexico are community property states and define community property as being all property acquired during marriage that is not separate property. ${ }^{31}$ Separate property is generally property acquired by gift, devise, bequest, or descent, or designated as

28. Union Pac. Res. Co. v. Hutchison, 990 S.W.2d 368, 371 (Tex. App.-Austin, 1999 , pet. denied).

29. 43 C.F.R. $§ 3181.3$ (2019).

30. Brown v. Smith, 174 S.W.2d 43, 46-47 (1943).

31. N.M. StAT. ANN. § 40-3-8(B) (2019); TeX. FAM. CodE ANN. §3.002 (West 2019). 
separate property in a writing signed by both spouses or by court judgment. ${ }^{32}$ However, there are a few minor distinctions related to the treatment of marital property between Texas and New Mexico. For example, in New Mexico, property acquired by a woman prior to July 1, 1973 through an instrument in writing in her name alone was presumed to be her separate property. ${ }^{33}$ Additionally, while Texas has accepted common law marriage, in New Mexico, common law marriage cannot establish rights in property. ${ }^{34}$ A more significant difference in the treatment of marital property between the two states is that Texas recognizes sole management community property, meaning that if property is conveyed to one spouse, that spouse is able to exercise sole management, control, and disposition of that property during the marriage, assuming both spouses are still living. ${ }^{35}$ In New Mexico, both spouses must join in any transfer, conveyance, or mortgage of any community property, and if they do not join, that conveyance is void and has no effect. ${ }^{36}$ However, it can be later validated by a ratification in writing from the other spouse. ${ }^{37}$

\section{DESCENT AND DISTRIBUTION}

The laws of the state where property is located is determinative to pass property upon the owner's death, even if the decedent was domiciled in a different state. ${ }^{38}$ Both the laws of intestacy, meaning property passing under the state's laws in the absence of a will, and the requirements for probating an estate, with or without a will, have some notable distinctions between New Mexico and Texas. The differences start by recognizing that New Mexico has adopted the Uniform Probate Code, while Texas has its own Estates Code. ${ }^{39}$

For purposes of comparing the laws of intestacy, we will focus on the passage of title upon the death of a married person with children. July 1, 1959 is an important date when discussing New Mexico's laws of descent and distribution. Prior to this date, if the

32. N.M. StaT. ANN. § 40-3-8(A) (1978); TeX. FAM. CODE $§ 3.001$ (West 2019).

33. N.M. STAT. ANN. § 40-3-12(B) (1978).

34. TEX. FAM. CODE $§ 2.401$ (West 2019); In re Gabaldon's Estate, 34 P.2d 672, 674-75 (N.M. 1934).

35. TEX. FAM. CODE $§ 3.102$ (West 2019).

36. N.M. STAT. ANN. § 40-3-13 (1978).

37. N.M. STAT. ANN. § 40-3-13(B) (1978).

38. Robby Alden, Modernizing the Situs Rule for Real Property Conflicts, 65 TEX. L. REV. 585 (1987).

39. N.M. Stat. AnN § 45-1-301 (2019); See generally TeX. Est. Code. AnN. (West 2015). 
wife died, all her community property interest would automatically pass to her husband. Additionally, until July 1, 1973, the wife did not have testamentary authority to devise community property. However, upon the husband's death, five-eighths of the total community property interest would pass to the wife through intestacy and threeeighths would pass to the children. Since July 1, 1959, when a person dies without a will, all community property passes $100 \%$ to their spouse. Further, from June 12, 1959 until July 1, 1973, if a husband died intestate, all community property passed to his wife without the necessity to probate his estate. This is one of the few exceptions to the requirement of an estate administration in New Mexico.

In Texas, before September 1, 1993, upon the death of one spouse, the surviving spouse only retained their one-half community property interest, while the decedent's one-half was divided equally among the children. ${ }^{40}$ Since September 1, 1993, upon the death of one spouse without a will, the entire community property estate passes to the surviving spouse. Therefore, today, the passage of community property through intestacy is treated the same in both states. ${ }^{41}$ Separate property in New Mexico passes one-fourth to the surviving spouse and three-fourths to the children through intestate succession. Separate property in Texas passes two-thirds in fee simple to the children and one-third to the children, subject to a life estate in the surviving spouse. $^{42}$

When determining the share attributable to each heir through intestacy, from statehood until June 1, 1993, New Mexico distributed shares per stirpes, which is the method that Texas still uses today. This means that the estate is divided into as many shares as there are heirs in the nearest degree of kinship and deceased persons in that same degree who left surviving issue. Each generation is treated by the root and there is no combination of second-degree kin. Since June 1, 1993, New Mexico distributes intestate shares by representation, which means that the same method determines the number of shares but distributed per capita with the combination of second-degree kin.

In the absence of a will, Affidavits of Heirship, including facts surrounding the death and legal heirs, are often filed in the county where a decedent's real property is located. Affidavits of Heirship are not sufficient to pass marketable title in New Mexico. However, in

40. Tex. Prob. Code $\S 45$ (West 2019); Tex. Prob. Code $\S 38(\mathrm{~b})(1)$ (West 2019).

41. Tex. Est. Code AnN. $\S \S 201.002(b), .003(b)(2)$ (West 2020).

42. $\S 201.002(b)$. 
practice, many operators will rely on Affidavits of Heirship to release funds due to mineral owners for small interests. In Texas, if an Affidavit of Heirship has been filed of record for more than five years and was executed by two disinterested parties, it is received by the court as prima facie evidence of the facts contained therein. ${ }^{43}$

With or without the existence of a will, the laws surrounding the administration of decedents' estates also differ between Texas and New Mexico. In New Mexico, a probate proceeding is required for title to be considered marketable. ${ }^{44}$ In both states, a will is not effective to pass title until it is admitted to probate, and the passage of title relates back to the date of death. However, a major difference is that if real property is located within the state of New Mexico, an instate administration of the estate is required. This is true even if the estate was already administered in a different state and can be done via an original or concurrent probate with the proceedings in the decedent's domiciliary state, an ancillary probate proceeding, or a short form proceeding. ${ }^{45}$ Further, personal representatives are required to execute a distribution deed to evidence the passage of title from the estate. ${ }^{46}$ While Texas code provides for similar proceedings for the estates of out of state decedents, they are less often utilized because an exemplified copy of a foreign will, along with a copy of the judgment, order, or decree, can be filed and recorded in any Texas county in which decedent's land is located without the necessity of conducting probate proceedings in a Texas court. ${ }^{47}$ Therefore, a recorded foreign will in Texas has the same effect as a domestic will and provides constructive notice of the transfer of real property. ${ }^{48}$

There are specific vehicles in both states to pass title without the necessity of probate. For example, parties can own property as joint tenants with right of survivorship, which would immediately vest title in the surviving joint tenant upon the death of one tenant. ${ }^{49}$ In Texas, joint tenancy between married persons was difficult to establish prior to 1987 , at which time the Texas Constitution was amended to say, "[s]pouses may agree in writing that all or part of their community

43. Tex. Est. Code AnN. $§ 203.001$ (West 2019).; Tex. Prop. Code AnN. Tit. 2-App. TeXas Title EXAmination StAndard 11.70; N.M. STAT. ANN. § 45-1302 (2019).

44. N.M. STAT. ANN. § 45-1-302 (2019).

45. N.M. STAT. ANN. §§ 45-3-201, 308; 45-4-204, 207 (2019).

46. N.M. STAT. ANN. § 45-3-907-908 (2019).

47. TEX. Est. CODE ANN. $§ 503.001$ (West 2020).

48. Id.

49. Swink v. Fingado, 850 P.2d 978 (N.M. 1993). 
property becomes the property of the surviving spouse on the death of a spouse." 50 However, in both states, joint tenancy between spouses or a spouse and a third party does not destroy the presumption of community property. Transfer on death deeds are another method to provide for the non-probate passage of title. ${ }^{51}$ The New Mexico code also allows married persons to transfer title to their homestead by affidavit, while in Texas, a probate is not required for community property to pass to the surviving spouse when a spouse dies intestate. ${ }^{52}$ A small estate affidavit can be utilized to pass title in Texas for estates valued at less than $\$ 75,000 .^{53}$

\section{CONCLUSION}

This Article is intended to only highlight a few basic differences between Texas and New Mexico oil and gas law from a title examiner's perspective. One could write an entire paper on the many distinctions discussed herein. In today's energy industry, significant exploration and operation of oil and gas occurs in New Mexico and Texas. Accordingly, it is common for professionals to crossover between the two states, which makes awareness of the differences essential.

50. TEX. Const. art. XVI, $\S 15$.

51. N.M. StAT. ANN. § 45-6-401 (2019); TEX. Est. CODE ANN. $\$ 114.05$ (West 2020).

52. N.M. Stat. AnN. § 45-1-1205 (2019); TeX. Est. CodE AnN. $§ 453.002$ (West 2020).

53. Tex. Est. Code AnN. $§ 205.001$ (West 2020). 